Roberto Laghi*

Avignon University

\title{
Fiction, Science Journalism: Hybrid Narrative Paths for Our Challenging Present
}

\begin{abstract}
:
In this article I will explore the hypothesis that hybrid narrative forms (consisting of journalism, fiction and scientific knowledge) can be more effective in the task of narrating the present of the so-called Anthropocene, marked by the climate crisis and the consequences of neoliberal politics. As a first and fundamental step, I underline the need for a critical work on the language that dominates our societies, through the analysis of Personne ne sort les fusils by Sandra Lucbert. I then briefly consider the role that scientific information and its popularization can play in the hybridization of narrative forms, taking as an example the short story by Ted Chiang "The Evolution of Human Science". I conclude by analysing Storie della grande estinzione by the Italian collective author TINA, which, with its coexisting different forms of fiction, essay, popular science and critical theory, is not only a clear example of this hybridization but also provides an important mythopoetic dimension based on these same forms.
\end{abstract}

Keywords:

Language, journalism, fiction, Anthropocene, scientific popularization, mythopoesis

\section{Sintesi:}

In questo articolo indagherò l'ipotesi secondo cui forme narrative ibride (basate su giornalismo, fiction e conoscenza scientifica) possono essere più efficaci nel narrare il presente del cosiddetto Antropocene, segnato dalla crisi climatica e dalla conseguenze delle politiche neoliberali. Come primo e fondamentale punto, sottolineerò la necessità di un lavoro critico sul linguaggio predominante all'interno nelle nostre società attraverso l'analisi di Personne ne sort les fusils di Sandra Lucbert. Considererò poi brevemente il ruolo che informazione e divulgazione scientifica possono giocare nell'ibridazione delle forme narrative, prendendo come esempio il racconto di Ted Chiang "The evolution of human science". Concluderò con l'analisi di Storie della grande estinzione, dell'autore collettivo italiano TINA, un libro che, grazie al coesistere di forme diverse di fiction, saggistica, divulgazione scientifica e teoria critica, non rappresenta solo un chiaro esempio di questa ibridazione ma offre anche un'importante dimensione mitopoietica, costruita attraverso queste stesse forme. 
Parole chiave:

Linguaggio, giornalismo, narrativa, antropocene, divulgazione scientifica, mitopoiesi

\begin{abstract}
La predisposizione umana alla narrazione fittizia (fiction) sembra a prima vista controproducente in senso biologico rispetto alla narrazione vera (true narration), che veicola informazioni utili alla sopravvivenza o che, in forma di gossip, svolge una funzione di coesione sociale.

Perché, allora, l'umanità spende tanto tempo nel raccontare storie che non sono credute né da chi narra né da chi ascolta?

[The human disposition to fictional narration (fiction) appears at first sight counterproductive in a biological sense to true narration, which transmits information that is useful for survival or which, as gossip, contributes to social cohesion.

So why does humanity spend so much time telling stories that are not believed either by those who narrate nor by those who listen?]
\end{abstract}

(TINA 2020: 245)

\title{
Introduction
}

There are, of course, multiple approaches to analysing the mutual contaminations of journalism and literature. To impose some necessary limitations, in this article I will focus on contemporary written production and, particularly, on three texts that can be considered hybrids between journalism (including the popular essay) and fiction. These texts can be looked at as attempts to expand the boundaries of narration by means of inserting other writing forms such as scientific popularization, critical analysis and the representation of the imaginary which, in combination, can show us new and different ways of thinking about literary forms for the Anthropocene. ${ }^{1}$

I support the hypothesis that these hybrid forms can give birth to deeper and more articulated narrative possibilities and better ways to understand the complexity of contemporary reality. In particular, I will argue, with the collective author TINA, that this hybrid narrative forms are necessary because "solo un equilibrio consapevole tra conoscenza scientifica, grammatica dell'immaginazione e vocazione politica potrà produrre i manuali necessari per affrontare i prossimi tempi, per salvarci" ["Only a conscious balance between scientific knowledge, the grammar of the imagination and political vocation will enable us to produce the handbooks necessary for us to confront what is to come, to save ourselves." ${ }^{2}$ (TINA 2020: 444). 
As Marco Caracciolo has recently pointed out:

It is not a coincidence that the most stimulating negotiations of the Anthropocene crossfertilize storytelling with other genres and semiotic modes, integrating the visual language of science (e.g., in Rivka Galchen's Atmospheric Disturbances) and essayistic discourse (in Safran Foer's 2019 book as well as works by another American writer, Thalia Field) to hint at the blind spots and inadequacies of narrativity. Such blurring of generic and semiotic boundaries might be useful, and even essential, in times that are challenging so fundamentally the ontological categories handed down to us by Western modernity. (Caracciolo 2020: 29) ${ }^{3}$

As a starting point, I will first address the "political vocation" mentioned above in relation to the use of language as a tool to manipulate reality (and the interpretation we can make of it) and, in particular, to limit the spectrum of critical discourses we can generate. I consider that a critical work on language is a fundamental step not just to select the tools but also to reclaim collective possession of those tools we need, as mankind, to grasp and narrate the present. Above and beyond the debate around fake news and the crisis of journalism, ${ }^{4}$ and following the example of a fundamental study of the language of power, such as LTI by the philologist Victor Klemperer, we can argue that our societies have been pushed to adopt a "newspeak" whose consequences go even further than those George Orwell imagined in Nineteen Eighty-Four, and do so in ways that are different. I will investigate the role of this "newspeak" by analysing Personne ne sort les fusils by Sandra Lucbert, with the help of the work of the French economist Jean-Paul Fitoussi, whose recent books highlight the use of language in the dominant neoliberal discourse. Lucbert aims to deconstruct this newspeak by way of situating herself, as a writer, in a position that is external to the linguistic system she criticizes. Hybridization between fiction and non-fiction is key in this attempt because it allows a deeper understanding of what is at stake than that which journalism or literature alone could have provided.

I will then add, also as a form of liaison, a few notes about the short story "The Evolution of Human Science" by Ted Chiang, first published in Nature magazine, as a means of identifying scientific information and its popularization as another important element in the process of narrative hybridization: in times of pandemic, we have seen that this is a key point, and closely related to language, journalism and our ability to understand the world. Furthermore, this particular example of (science-scientific) fiction took the form of journalism, and involved confronting some of the issues posed by technological development and Artificial Intelligence, and, in doing so, addressed fundamental questions about humanity and its present and future relationship with machines.

Political vocation, scientific knowledge and the construction of the imaginary (mythopoesis) are well combined in the third work I consider, Storie della grande estinzione by the collective author TINA, a book that mixes fiction, essays and critical theory. The aim of this book, in line with the literary oriented Anthropocene production, is dualistic: on the one hand, it is meant to make us (more) familiar with the ideas of catastrophe and collapse 
(and to an extreme extent: the end of humanity as we know it), and, on the other, to create new collective narrations (myths) that can help us to think on the contemporary world physical environment and human life conditions, which "seem[s] to have become cognitively unthinkable" (Monacelli 2020: 122).

With the awareness that this effort to map and identify certain elements of contemporary writing is necessarily limited and reflects just one of many possible lines of inquiry, these texts will help us to examine the hypothesis I have presented and, as a conclusion, to imagine possible new trends in the representation of reality.

\section{The tools: "hacking" the "newspeak"}

Sandra Lucbert's Personne ne sort les fusils ${ }^{5}$ tells the story of the France Télécom trial, that started on May $6^{\text {th }} 2019$ and ended on December $20^{\text {th }} 2019$, convicting in first instance seven managers of the company. The legal battle was started in 2009 by former employees and their families who wanted the "moral harassment" caused by the company management to be acknowledged in court. The story has been widely reported by the media (especially by French sources), in particular during the so-called "suicides crisis" of 2009. The reorganization of the company that led to a crisis situation and then to the trial is considered one of the most rigorous examples of the enforcement of neoliberal politics in France. ${ }^{6}$

Lucbert attended the sessions of the trial and, with an "unspeakable rage"7 on what she had witnessed, asked herself how she could write about this story. "Le procès France Télécom est l'histoire d'un enlisement grammatical" ["The France Télécom trial is the story of a grammatical subsidence"], she writes (Lucbert 2020: 21): the only way she found to tell the story of this "subsidence" was to unmask the grammar and language that sustains it, and to deconstruct its mechanisms and automatisms.

"Les mots d'une société ne contiennent qu'elle" [The words of a society are but meant to hold the society itself] (idem: 33). Although the France Télécom case was reported across the print and electronic media, there seemed to be a threshold beyond which commercial mainstream journalism cannot but fail. The fact-checking trend of recent years, instead of being proof of the continuity of the role of journalism as a watchdog, is the avowal of its failure: that journalism itself no longer involves fact-checking, a service now provided by specialist teams, demonstrates beyond doubt that it has lost its foundations. This could be one of the reasons for why journalism often fails to grasp the complexity of the present time frame; even when facts are verified and explained, there remains something scarcely placed under scrutiny: I mean the system in which the reported facts have taken place. In the specific case of the France Télécom trial, we know what happened, we know about the economic plan and the moral harassment, about the cases of clinical depression and the deaths by suicide; we have the numbers, the facts, the dates. But something remains hidden between the lines, wiped out by the "newspeak". That same newspeak which is also the language of mainstream journalism, the same used by the mainstream political and economic discourse, the language that shapes our societies and supports a social order that is reproducible, mechanical. In the 
France Télécom trial, the social order being judged is the same one that sits in judgement, and therefore "toute notre mécanique sociale devrait comparaître" ["our entire social mechanism should appear in court"] (idem: 19). Now, this mechanism "se voit uniquement en s'extirpant de la langue générale" ["can be seen only by uprooting oneself from the general language"], because "depuis un ailleurs, le machinal ressemble souvent à une torture énigmatique" ["looked at from an elsewhere, its mechanics often look like an enigmatic torture"] (idem: 25).

To construct this "elsewhere", Lucbert deploys two methods. Her first approach is to use literature as a "quantité d'états de langage" ["a number of states of language"] (ibidem) that can be extremely useful in maintaining a constant déplacement ["distancing"] from the object under observation, since literature imposes "un écart permanent d'avec tout ce qu'on dit" ["a permanent departure from everything that is said"] (ibidem): these literary references (pages from Proust and Rabelais as well as Kafka's The Penal Colony and Melville's Bartleby) create a "cacophonie interiéure" ["inner cacophony"] (ibidem) that enables the author to break the collective language (of which she acknowledges to be herself a speaker, too, of course). Her second approach consists of a constant switching between different literary styles: narration, journalism, critical essay, monologues in free verse. This way of adapting writing forms to the needs of representation helps overcome the boundaries between different genres, and allows the author to create a hybrid text that better meets the challenge of the critical thought she is engaging in.

Even if Lucbert uses the term "newspeak" ("novlangue" in French, more recently translated from the English as "néoparler"), borrowed from George Orwell's Nineteen EightyFour, the most important reference for her work is the German philologist Victor Klemperer and his analysis of Nazi power language; hence her use of the term "LCN", "Lingua Capitalismi Neoliberalis", a Latin loan expression that comes directly from Klemperer's "LTI" or "Lingua Tertii Imperii", the language of the Third Reich. Nazi power colonized the language word by word, sentence by sentence, repetition after repetition, in such a way that their language, that of the victors, was assimilated by almost everyone, including the victims. The more unconscious this assimilation was, the more it shaped the speech, thought and feelings of the people. The same is happening nowadays with the language of neoliberal economics, warns Lucbert. The "liquid" language of this shaping process advances through "glissements lexicaux" ["lexical slippages"] (idem: 31) - or "piège[s] sémantique[s]" ["semantic traps"] to use the words of Jean-Paul Fitoussi (2020: 129). It uses words and sentences to manipulate reality and to hide causes, since "sans compréhension de la cause, on n'aperçoit pas la cause" ["without understanding the cause, you cannot discern the cause"] (Lucbert 2020: 132). As a consequence, we take reality as it is, without any critical thinking. As examples of how the LCN operates, as Lucbert points out, in the newspeak one is not supposed to say that people are being "protected" but instead that they are "on benefits", and workers are described as "associates" or "partners" rather than "employees".

Lucbert dissects this newspeak in a way that is reminiscent of hacking practices in the software world: studying the structure (the code, the language), exposing its weaknesses and 
exploiting them in order to do something else, something hitherto not thought of, not allowed. As Arjun Appadurai stresses, "the replacement of society by the market" also occurred thanks to the creation of its own fully-fledged cosmology with "a rich stock of narratives, scripts, and stories", by means of a constant use of mass media. This cosmology, Appadurai continues, "also pulls the rug out from any sort of Durkheimian hope for connectivity, solidarity, and moral community. The challenge both for anthropology and for us as citizens is how to make this observation the foundation for new forms of critique and resistance" (Appadurai 2016: 69).

In her work on language, Lucbert looks exactly for these new forms of critique and resistance: if we are to build a new imaginary for our time, the base-line for this mythopoesis should be the use of a language that is related to the reality one experiences and not by employing a newspeak as a tool of concealment.

As Fitoussi remarks, "les mots sont liées aux choses; les détacher d'elles les prive de sens" ["words are linked to things; to disconnect them from things deprives them of meaning"] (2020: 37), and that is exactly what newspeak does; this "appauvrissement du langage" ["impoverishment of language"] (idem: 5 ) limits our ability to understand reality just as we are facing the unprecedented challenges of climate change, and a global health and socioeconomic crisis, which are consequences of predatory neoliberal capitalism.

If one takes a deeper look at the effects of this use of language one can say, with the Italian jurist Gustavo Zagrebelsky, that "il linguaggio acriticamente accettato esercita qualcosa come una dittatura simbolica" ["uncritically accepted language exerts something like a symbolic dictatorship"] (2010: 57). Western "post-democracies are in the business of population management. [...] Like the algorithmic protocols of the digital platforms [they do not] negotiate with our wants, [they] shape what we are capable of wanting" (Seymour 2019: 173). These analyses make quite clear why it is essential to deconstruct the dominant language in order to adopt a critical idiom that will allow us to build a new imaginary.

Furthermore, this newspeak, with the considerable help of media and technology, ${ }^{8}$ forces us into a continuous present: Lucbert's language-hacking reveals to us that "un monde n'est pas inéluctable; c'est une version des rapports humains temporairement victorieuse" ["a world is not ineluctable; it is a version of those human relations which are temporarily victorious"] (Lucbert 2020: 131). So, if a language is historically situated, having a historical perspective can play a fundamental part in building narratives for our times, and, to do so, journalistic elements in fiction can be decisive, as we will see also in the fourth section of this article.

As a last point in this analysis of the use of language, I would like to address what Laura Tripaldi, in an interview, referred to as the "inadequacy of language":

la nostra cultura - Haraway, nelle orme di Luce Irigaray, la definisce spesso 'fallogocentrica' - ci ha abituati all'idea che è sempre la parola a definire la materia, e mai viceversa. Fortunatamente, chi ha familiarità con la scienza e la tecnologia sa bene che, nella maggior parte dei casi, avviene esattamente il contrario: è il nostro linguaggio che deve continuamente modificarsi per adattarsi alla materia e alle sue trasformazioni. 
[Our culture - Haraway, following in the footsteps of Luce Irigaray, often defines it as "fallogocentric" - has got us used to the idea that it is always the word that defines matter, and never the other way round. Luckily, as those who are familiar with science and technology well know, in most cases it's exactly the opposite that happens: it is our language that has to change constantly to adapt to matter and its transformations.] ${ }^{9}$

This necessity for language to adapt to matter and its transformations has to be taken into consideration as a part of the hybridization process that combines scientific knowledge, fictional narration and journalism/essay: as climate crisis deepens and technological development speeds up and conquers more and more aspects of our everyday life, language needs to follow and adapt - again, in a never-ending effort to better grasp reality. In the same interview, Tripaldi continues:

pensiamo ad esempio alle formule chimiche, una specie di "linguaggio in codice" fatto di lettere e segni che ci permette di descrivere lo strano mondo degli atomi che reagiscono tra loro. Forse la scienza mi appassiona proprio per questo: perché è una specie di via di fuga dal linguaggio, o meglio, un modo per ritornarci sempre arricchiti di parole nuove. E queste nuove parole non sono mai definizioni ma passaggi segreti, fili di ragnatela che ci permettono di spostarci da una parte all'altra della rete che ci connette, per stringere nuove alleanze e scoprirci meno soli.

[let us think, for example, about chemical formulas, a kind of "code language" made of letters and signs that allows us to describe the strange world of atoms interacting with each other. Probably, I'm passionate about science for this very reason: because it is a kind of escape route from language, or better, a way to get back to it enriched by new words. And these new words are never definitions but secret passages, cobwebs that allow us to move from one side of the net connecting us to the other, to forge new alliances and to find ourselves less alone. ${ }^{10}$

\section{When (science) fiction is journalism is (scientific) fiction}

Science fiction has always worked with/from a different "place" (be it u-topia or dystopia): this déplacement creates the conditions for an externality from which to look at our society, all the better to be able to observe it, criticize it and shed some light on trends and tendencies that may trace paths to possible futures. As we have seen with Lucbert, there are various techniques to achieve this externality, such as focusing on language, as she does.

Ted Chiang is a well-known science fiction author whose work is remarkable especially due to his skilful attempts to use new narrative means to explore the socio-cultural challenges of our time. Here I want to focus on one of his short stories, "The Evolution of Human Science", written at the invitation of the British science journal Nature and later published in the author's 2010 collection Stories of your Life. The task set by the journal, as Chiang himself explains in his notes to the story, was to provide "a short fictional treatment of a scientific development occurring in the next millennium" (Chiang 2010: loc. 6263). Thus, while a science journal was 
asking for fiction to be written about science, Chiang went a step further: "since the piece would appear in a scientific journal, making it about a scientific journal seemed like a natural choice. I started wondering about what such a journal might look like after the advent of superhuman intelligence" (ibidem). This is the reason why this particular short story immediately came to mind when I was thinking about the need to incorporate scientific knowledge into fictional writing and about hybrid forms that were able to cross boundaries between genres.

In the fictional future created by Chiang, experimental scientific research is dominated by "metahumans" who are able to make their findings available through "DNT (digital neural transfer)", a language that humans grasp less and less the more metahumans develop it. The consequence is that humans are left out of science, except for hermeneutics, that is to say, "interpreting the scientific works of metahumans" (idem: loc. 2989). In Chiang's world, hermeneutics "is a legitimate method of scientific inquiry and increases the body of human knowledge just as original research did", and could help humans "discern applications overlooked by metahumans, whose advantages tend to make them unaware of our concerns" (idem: loc. 3012). Hermeneutics, as one example in the story explains, could lead to the discovery of an "intelligence-enhancing therapy" (ibidem) that would allow individuals to "up-grade" so they could understand metahuman language, an issue in which metahumans would have little interest.

However, one can read this story on another, quite distinct (science-fictional) narrative level: the problem of a dominant language that prevents humans from understanding reality. ${ }^{11}$ In Chiang's fiction, it is future scientific research that alienates human society from reality, while in Lucbert's non-fiction, it is the newspeak of political and economic power that structures our societies.

Chiang, in staging a debate on the role of humans in scientific research at a time when more-than-humans have already taken control of the field, also questions the relation between humans and Artificial Intelligence that is crucial to contemporary debates: "What is the role of human scientists in an age when the frontiers of scientific inquiry have moved beyond the comprehension of humans?" (idem: loc. 2981). By posing this question in a fictional work, he also identifies these themes as matters of interest to narrative fiction, highlighting the importance of the relations between science and narrative in the Anthropocene, ${ }^{12}$ an era that "presents a challenge not only to the arts and humanities, but also to our common-sense understandings and beyond that to contemporary culture in general" (Ghosh 2016: loc. 109).

\section{The (hybrid) quest for mythopoesis}

Storie della grande estinzione is a work curated by Italian writers Matteo Meschiari and Antonio Vena, published under the collective authorial name of TINA. ${ }^{13}$ It is a hybrid form that not only defies the boundaries of various genres, but does so with a programmatic intent that also includes visual content (illustrations) as a fundamental part of this hybridization.

Examples of this intent can be found throughout the text, such as the quote mentioned in the introduction to the present article or the following passage that echoes Ballardian landscapes: 
"C'èanche una discussione aperta tra più autori, diverse discipline, piani teorici che associano geni e meme, informazione e byte e DNA e ancora manipolazione delle informazioni, delle narrative e poi editing genetico. Siamo pronti ai virus narrativi" [ "There is also an open discussion among many authors, in different fields, with theoretical frameworks associating genes and memes, information and bytes and DNA, and now linking the manipulation of information, narrative and genetic editing. We are ready for narrative viruses"] (TINA 2020: 271).

The building of a "nuova tecnologia dell'immaginario" ["new technology of the imaginary"] (idem: 100) must start from the observation that everything is connected, tout se tient, as the lines cited above seem to suggest. That is why to narrate the present state of affairs implies, for the collective author TINA, adopting a historical and chronological perspective: one has to locate our presence as humankind in a story that begins before and without the human species and will probably continue after its extinction. That means also to reject the contemporary pressure to live in the flow of a constant present (see note 8).

And, since everything is connected (as quantum field theory also suggests), the functional role of language, i.e. the lexicon, is, again, fundamental: "il lessico è centrale. Selezionare il lessico è centrale. Rifondare il lessico è centrale. Adottare quotidianamente il lessico è centrale. Fa tutta la differenza tra narrazioni empatiche e narrazioni di soluzione. Fra storytelling dello status quo e realizzazione del Fiction is Action" [ "the lexicon is pivotal. Choosing your lexicon is pivotal. Refounding the lexicon is pivotal. Using your lexicon on a daily basis is pivotal. It makes all the difference between empathic narratives and narratives of solution. Between the status quo storytelling and the accomplishment of Fiction is Action] (idem: 77).

The book follows the model of Boccaccio's Decameron, dividing the many stories into thematic days, in this case seven rather than ten. In these seven parts, which follow a chronological order, one finds accounts of historical events that can take either fictional or factual form: from the first encounter between homo sapiens and homo neanderthalensis more than 40,000 years ago, to the plague in Athens in $430 \mathrm{BCE}$, from the Lisbon earthquake of 1755 to the Bhopal disaster of 1984, just to name a few. Then a few mainly fictional passages about the present give way to fictional accounts of imagined possible futures. Some of these short stories are also depicted as illustrations that enrich the book with an extra-linguistic narrative form. Intertwined with these texts, one finds fragments that function as means to connect and contextualize the plot and also provide scientific, historical and cultural information that contributes to the theoretical and critical structure the authors are erecting.

Some of the short stories, and especially those that take place in the $20^{\text {th }}$ and $21^{\text {st }}$ centuries, provide relevant examples of the hybridization of journalism and fiction. "Il suicidio dei pinguini" ["The suicide of penguins"] (idem: 45) talks about the discovery of the neurological Minamata disease: it begins with an introduction that sets out some of the relevant philosophical implications (e.g. the problem of suicide as interpreted by Albert Camus) and makes reference to the cinema of Werner Herzog; it then tells the story of the discovery of the consequences of mercury poisoning and the questions and fears that arose among the population of the Japanese city back in the fifties, making use of a form of writing that includes 
scientific popularization and can be referred to as literary journalism.

This is the same narrative device the authors used in "Estonia. Siljia Europa. Estonia. Siljia Europa" (idem: 121) on the sinking of the cruise ferry Estonia in 1994: this chronicle of the dramatic accident could well have appeared in a newspaper of the time or been written by a reporter dedicated to finding out the truth about what happened, and even looking into the conspiracy theories the tragedy brought forth.

Even when the stories are entirely fictional, the short fragments connecting them often use scientific references, historical contextualization and quotes by authors from different fields. This narrative strategy allows the collective author to provide the reader with a perception of unity and continuity, a strong sense of cohesion.

Storie della grande estinzione is a powerful example of just one of the many ways in which contemporary writers make use of hybrid narrative forms. Although genre hybridization has long existed, these stories, through their specific contemporary plots, may be regarded as an attempt to create what Amitav Ghosh calls "moments of recognition" (Ghosh 2016: loc. 49), i.e. moments in which we witness the ability of non-human forces "to intervene directly in human thought" (idem: loc. 423). Those non-human forces are the natural elements that, in these times of dramatic climate change, impose their presence and demand to be taken into account, not just in our everyday life but also in the way we culturally interpret reality. The statement "fiction is action" (TINA 2020: 77, 167) presupposes such moments of recognition can occur also in the case of a literary object (and not only an unprecedented climate event, as described in Ghosh's book).

It is perhaps this non-human presence that differentiates contemporary from past hybrid narrative forms, providing a return to the novel's portrayal of "forces of unthinkable magnitude that create unbearable, intimate connections over vast gaps in time and space" (Ghosh 2016: loc. 877). This return not only poses the problem of memory (as a collective mechanism) but also of the need to "immaginare l'impossibile per sopravvivere all'imprevedibile" ["imagine the impossible to survive the unforeseeable"] (TINA 2020: 193). To put it in the words of Amitav Ghosh:

If literature is conceived of as the expression of authentic experience, then fiction will inevitably come to be seen as "false". But to reproduce the world as it exists need not be the project of fiction; what fiction - and by this I mean not only the novel but also epic and myth - makes possible is to approach the world in a subjunctive mode, to conceive of it as if it were other than it is: in short, the great, irreplaceable potentiality of fiction is that it makes possible the imagining of possibilities. And to imagine other forms of human existence is exactly the challenge that is posed by the climate crisis. (2016: loc. 1753)

This is precisely the challenge that the authors involved in the writing of Storie della grande estinzione have taken up with their hybrid work of constructing a new imaginary. 


\section{Conclusions}

If, in the past, literature and journalism have competed with and comple(men)ted each other to find deeper and more meaningful ways to represent reality, ${ }^{14}$ the challenges posed by the complexity of our contemporary globalized world probably call for new forms of contamination and cross-pollination between these genres and beyond them.

As I have tried to argue in this article, by way of an examination of selected hybrid narrative objects, while the possibilities opened up by hybridization could be multiple and non-exclusive, they will also probably offer (and are already offering) useful semiotic means to deepen collective awareness, as humanity struggles to understand the natural phenomena that climate change is unleashing, many of them a consequence of the economic and social impact of the neoliberal policies that have been adopted at a global level over recent decades.

If it is true that, as TINA says, "l'Antropocene [...] è a tutti gli effetti il tentativo di fondare una nuova cosmologia" ["In effect, the Anthropocene (...) is the attempt to found a new cosmology"] (TINA 2020: 407), then an even greater truth is that in order to do so we must first tear down the newspeak that prevents us from grasping reality at its fullest; that is why I consider working critically on language a primary and fundamental step.

The hybridization between genres could also go further, in ways that may include moving "beyond language" (Ghosh 2016: loc. 1159) by taking into consideration "patterns of communication that are not linguistic" (ibidem). This is an issue the Italian writer Giuseppe Genna addresses when he points to non-textual horizons for the interpretation of reality:

La breccia Covid mi dice che siamo entrati in una categoria molto diversa da quella del testo e molto diversa da quella dell'immaginario. [...] Siamo veramente in uno spazio clamoroso di neo-percezione umana che si amplificherà sempre di più andando avanti perché l'ingresso di tutti i device, tutte le neotecnologie e le nanotecnologie nel corpo di aprirà nuovi orizzonti sensoriali e interpretativi della realtà. [...] Ci dobbiamo riformulare tutto, reinventare tutto, questa reinvenzione io non credo che sarà testuale.

[The Covid rupture tells me we have entered a phase that is very different from that of the written text and very different from that of the imaginary. [...] Now, we really are in a noisy space of human neo-perception that will amplify itself more and more as time goes by because all of the devices, all of the neotechnologies and nanotechnologies we will be carrying in our bodies, will open new sensory horizons and new interpretations of reality. [...] We have to reformulate everything, reinvent everything, I don't believe that this reinvention will be textual. ${ }^{15}$

This confluence of writing, new technologies, science and non-human forces, all insisting on a presence and vying for a place in our lives, will, of course, influence future trends and contaminations whose potential narrative forms we can barely start to imagine. 


\section{NOTES}

* Roberto Laghi, after a first MA in History and a second in Public and political communication, worked as a journalist, editor and consultant for about ten years. Now he is a Ph.D. candidate in Italian Studies at Avignon Université in joint supervision with Università di Parma in Italy. His research focuses on the influences and cross-pollinations between new technologies and writings about the present and how these influences impact on the representations of reality, in the context of the cultural production of the Anthropocene.

${ }^{1}$ The concept of "Anthropocene" was proposed by Paul Crutzen in 2000 "to capture [the] quantitative shift in the relationship between humans and the global environment" based on the evidence that "humankind, our own species, has become so large and active that it now rivals some of the great forces of Nature in its impact on the functioning of the Earth system" (Steffen et al. 2011: 843). As Crutzen himself, together with other researchers, explains, "the term Anthropocene suggests: (i) that the Earth is now moving out of its current geological epoch, called the Holocene and (ii) that human activity is largely responsible for this exit from the Holocene, that is, that humankind has become a global geological force in its own right. Since its introduction, the term Anthropocene has become widely accepted in the global change research community" (ibidem). Despite the fact that the Anthropocene has not (yet) been accepted as a geological era, it has become popular not just in the scholarly world but also in a wider global cultural debate, involving mainstream journalism, art and literature. While the scientific debate focuses mainly on the physical consequences of human activity on the planet and on when to situate the beginning of this era, the humanities are more concerned by the representations of these consequences and by how these changes "have affected our cultures and histories, driven wars and alliances, shaped our economies, and influenced the way people have been enslaved, subjugated, and exploited, from the age of agriculture to the age of steam and the microchip" (McManus, 2018: 45).

${ }^{2}$ Unless otherwise stated, all translations from French and Italian are mine.

${ }^{3}$ Using the term "negotiations", Caracciolo refers to the the concept of "narrative negotiations" as shaped by Luc Herman and Bart Vervaeck (Herman \& Vervaeck: 2017), who "embed narrative negotiations in a wider cultural and social context", and while admitting "that negotiations tend to involve tensions and conflicts [they] would like to stress these need not at all be resolved or even tempered in the course of the process" (idem: 619). In reference to the call for "new" stories for the Anthropocene, Caracciolo also challenges the concept of this newness "by drawing a link between novelty and complexity" (Caracciolo 2020: 19).

${ }_{4}$ The debate around these themes is enormous and ongoing. As a point of departure, I would refer to two works that I have found very useful: La disinformazione felice. Cosa ci insegnano le bufale by Fabio Paglieri (2020), with its very rich and upto-date bibliography on information, misinformation and malinformation; and Democrazie a rischio. La produzione sociale dell'ignoranza by Fabrizio Tonello (2019), whose analysis helps to situate the problem of information and journalism in contemporary societies.

${ }^{5}$ For a more detailed analysis of Lucbert's book, see Laghi 2020.

${ }^{6}$ Some of the best media coverage of the case during the years in question came from the French independent online media Mediapart, which constructed two dossiers, one on what happened at France Télécom and a second on the trial: <https://www. mediapart.fr/journal/france/dossier/dossier-france-telecom-des-suicides-au-proces>, and <https://www.mediapart.fr/ journal/france/dossier/france-telecom-chroniques-du-proces-d-un-harcelement-moral-grande-echelle> (last accessed on $28 / 12 / 2020$ ). 
7 Sandra Lucbert, interview in "Par les temps qui courent", France Culture, 18.09.2020. <https://www.franceculture.fr/ emissions/par-les-temps-qui-courent/par-les-temps-qui-courent-emission-du-vendredi-18-septembre-2020> (last accessed on 28/1/2021).

${ }^{8}$ As an example of this trend, Fabrizio Tonello writes of the "'flusso di coscienza giornalistico' dove l'imperativo della notizia in tempo reale sostituisce qualsiasi altro parametro, in particolare la verifica dei fatti, la credibilità, la contestualizzazione" ["the journalistic stream of consciousness in which the imperative of real time news replaces every other parameter, in particular fact-checking, trustworthiness, contextualization"] (2019: 46). The focus on "real time" implies that this stream keeps flowing, feeding a never-ending moment-to-moment succession of unrelated events; the same happens on social media platforms. To use the words of François J. Bonnet, "la sphère médiatique contribue elle aussi à une amnésie de plus en plus tenace, ou plus exactement à son acceptation" [ "the media sphere also contributes to a more and more relentless amnesia or, more precisely, to its acceptance"] (2017: 33). Zygmunt Bauman argued that "the novel instantaneity of time radically changes the modality of human cohabitation - and most conspicuously the way in which humans attend to (or do not attend to, as the case may be) their collective affairs, or rather the way in which they make (or do not make, as the case may be) certain affairs into collective ones" (2000: 126).

${ }^{9}$ Laura Tripaldi, interview published in the newsletter "Medusa - Vyta", <https://us15.campaign-archive.com/?u=6f14663 2ca91ad91d4b9dbd74\&id=d9b5e81a9d > (last accessed on 29/01/2021). The concept of phallogocentrism was first coined by Jacques Derrida.

${ }^{10}$ Laura Tripaldi, interview cited in note 9 above.

${ }^{11}$ Interviewed by Joshua Rothman of the New Yorker, Chiang claimed that language was a "recurring concern" in his work, and went on to develop his idea as follows: “There's a book by Umberto Eco called 'The Search for the Perfect Language' [...] It's a history of the idea that there could be a language which is perfectly unambiguous and can perfectly describe everything. At one point, it was believed that this was the language spoken by angels in Heaven, or the language spoken by Adam in Eden. Later on, there were attempts by philosophers to create a perfect language." Rothman, "Ted Chiang's soulful science fiction", <https://www.newyorker.com/culture/persons-of-interest/ted-chiangs-soulful-science-fiction> (last accessed on $31 / 01 / 2021)$.

${ }^{12}$ Just as narrative can assimilate and challenge forms of institutional control and political power, it can interact in complex and diverse ways with the forms of science. See, for example, Caracciolo 2019.

${ }^{13}$ As explained on the cover of the book, the name TINA is a reference to Tina Michelle Fontaine (1999-2014), a First Nation Canadian teenager who was reported missing and found dead in August 2014, "a micro-apocalypse that is part of the many low-intensity genocides that cause individuals, languages, traditions, worlds, possibilities, to disappear". At the same time, TINA hijacks the acronym for "There Is No Alternative", a slogan coined by Herbert Spencer and used by the likes of Margaret Thatcher and Francis Fukuyama to justify neoliberal policies.

${ }^{14}$ Without doubt, one of the most significant examples is John Steinbeck's The Grapes of Wrath.

${ }^{15}$ Giuseppe Genna, participation in an online debate entitled "Le parole e i racconti per l'Antropocene", Book Pride 2020, 25 October 2020, <https://www.youtube.com/watch?v=97G72jq3bDs> (last accessed on 5/11/2020). 
Cadernos de Literatura Comparada

Fiction, Science, Journalism: Hybrid Paths for Our Challenging Present

\section{Works Cited}

Appadurai, Arjun (2016), Banking on words, Chicago, University of Chicago Press.

Bauman, Zygmunt (2000), Liquid modernity, Cambridge, Polity Press.

Bonnet, François J. (2017), Après la mort. Essai sur l'envers du présent, Paris, Éditions de l'éclat.

Caracciolo, Marco (2019), "Form, Science, and Narrative in the Anthropocene" in Narrative 27

(3): 270-89 (October 2019).

-- (2020) "Negotiating Stories in the Anthropocene. The Case of Nathaniel Rich's Losing Earth", in DIEGESIS. Interdisciplinary E-Journal for Narrative Research / Interdisziplinäres E-Journal für Erzählforschung 9.2, 16-33. <https://www.diegesis.uni-wuppertal.de/index. php/diegesis/article/download/394/596>

Carbé, Emmanuela / Jacopo La Forgia / Francesco D'Isa (2020), Trilogia della catastrofe. Prima, durante e dopo la fine del mondo, Firenze, effequ.

Chiang, Ted (2010), Stories of your Life, Easthampton MA, Small Beer Press (ebook).

Fitoussi, Jean-Paul / Francesca Pierantozzi (curator) (2019), La neolingua dell'economia, Torino, Einaudi.

Fitoussi, Jean-Paul (2020), Comme on nous parle. L'emprise de la novlangue sur nos sociétés, Paris, Les Liens Qui Libèrent.

Ghosh, Amitav (2016), The great derangement. Climate change and the unthinkable, London, Penguin Books (ebook).

Herman, Luc / Vervaeck, Bart (2017), "A theory of narrative in culture", in Poetics Today 38:4 (December 2017), DOI 10.1215/03335372-4184265.

Klemperer, Victor (2010), LTI. La lingua del Terzo Reich. Taccuino di un filologo, (translation by Paola Buscaglione Candela), Firenze, Giuntina.

Laghi, Roberto (2020), "Sandra Lucbert, Personne ne sort les fusils, Paris: Seuil, 2020", in Sphères $n^{\circ} 5$ "Objectivité dans la recherche scientifique", https://hal.archives-ouvertes. fr/hal-03210917v1 .

Lucbert, Sandra (2020), Personne ne sort les fusils, Paris, Seuil.

McManus, Karla (2018), "How Anthropo-scenic!": Concerns and Debates about the Age of the Human, in Hackett, Sophie, Kunard, Andrea, Stahel, Urs (ed.) (2018), Anthropocene: Burtynsky, Baichwal, de Pencier, Fredericton, Goose Lane Editions.

Mbembe, Achille (2020), Brutalisme, Paris, La Découverte.

Monacelli, Enrico (2020), "Estinzione", in Demonologia rivoluzionaria, Roma, Nero, p. 115-126. Orwell, George (1991), 1984, New York, Penguin.

Paglieri, Fabio (2020), La disinformazione felice. Cosa ci insegnano le bufale, Bologna, il Mulino. Porcelluzzi, Nicolò (2021), "Medusa - Vyta", <https://us15.campaign-archive.com/?u=6f146 632ca91ad91d4b9dbd74\&id=d9b5e81a9d > (last accessed on 29/01/2021).

Rothman, Joshua (2017), "Ted Chiang's soulful science fiction", <https://www.newyorker. com/culture/persons-of-interest/ted-chiangs-soulful-science-fiction> (last accessed on $31 / 01 / 2021)$. 
Seymour, Richard (2019), The twittering machine, London, The Indigo Press.

Steffen, Will / Grinevald, Jacques / Crutzen, Paul / McNeill, John, (2011) "The Anthropocene: conceptual and historical perspectives", Phil. Trans. R. Soc. A.369842-867 http://doi. org/10.1098/rsta.2010.0327

Tonello, Fabrizio (2019), Democrazie a rischio. La produzione sociale dell'ignoranza, Milano, Pearson.

TINA (2020), Storie della grande estinzione, Perugia, Aguaplano.

Zagrebelsky, Gustavo (2010), Sulla lingua del tempo presente, Torino, Einaudi. 